\title{
TARTU RADIOCARBON DATES IX
}

\section{A LIIVA, G ELINA, V TCHATCHKHIANI, and T RINNE}

Institute of Zoology and Botany, Academy of Sciences of Estonian SSR,

Institute of Biology, Karelian Branch of USSR Academy of Sciences

The following list contains dates of organogenous sediments (peat and sapropel from the Karelian ASSR) made in 1972 to 1977 with the aim of studying the history of the development of peat bogs in the Holocene (Elina, 1969; 1971a,b; Pyavchenko et al, 1976). Samples were collected with Hiller or Instorf samplers. Borings were made in the deepest parts of the peat bogs.

Pollen analyses of all the sections described in this paper were conducted by V Tchatchkhiani; botanical analyses were made by L Belova. All samples were submitted for dating by the Institute of Botany, Karelian Branch of USSR Academy of Sciences.

Radiocarbon dates were determined by A Liiva and $\mathrm{T}$ Rinne, Biochemical Laboratory of the Institute of Zoology and Botany of the Academy of Sciences of the Estonian SSR.

Measurement of the activity of ${ }^{14} \mathrm{C}$ was performed by liquid scintillation with the use of benzene. All dated samples were measured in parallel on two single-channel units. Radiocarbon dates have been calculated using $5568 \pm 30$ as the half-life of ${ }^{14} \mathrm{C}$, with 1950 as the reference year.

\section{North Karelia}

Region covers territory of Karelia from its $\mathrm{N}$ boundaries, $66^{\circ} 30^{\prime}$ to $64^{\circ} \mathrm{N}$, excl SE Prebelomorye. List contains description of 16 samples of organogenous sediments coll from 9 peat bogs characteristic of different types of relief.

\section{Ptichye series}

Ptichye bog lies in Louhi dist near Lake Sokol in glacial moraine plain, $+120 \mathrm{~m}$. Fen peat bed, depth $7 \mathrm{~m}$. Two samples coll 1977 for dating by $\mathrm{O}$ Kuznetsov.

\section{TA-1021. Ptichye}

$$
8600 \pm 100
$$

Sample from basal peat layer at 6.7 to $7 \mathrm{~m}$ depth. Pollen analysis shows Boreal max of birch. Comment: date agrees well with palynologic materials from Kuusamo dist, Finland (Vasari, 1962).

\section{TA-1020. Ptichye}

$$
6610 \pm 100
$$

Peat from 4.5 to $4.75 \mathrm{~m}$ depth, contact of AT1/AT2. Empiric boundary of spruce pollen.

\section{Neino suo series}

Neino suo peat bog lies in Louhi dist near Lake Sokol in glacial moraine plain. Alt $+111.4 \mathrm{~m}$. Depth of fen peat, $5 \mathrm{~m}$. Two samples coll 1977 by O Kuznetsov. 
TA-1026. Neino suo

$8695 \pm 100$

Benthic peat layer underlain by clay from 4.75 to $5 \mathrm{~m}$ depth, contact of $\mathrm{B} 01 / \mathrm{B} 02$.

\section{TA-1025. Neino suo}

$7350 \pm 90$

Peat coll from 3.75 to $4 \mathrm{~m}$ depth, contact of B02/AT1.

\section{Mezhgornoye series}

Mezhgornoye (intermontane) bog lies in Louhi dist, S of Lake Sokol in deep basin with large ridge-like and hilly relief of denudate-tectonic genesis. Surface alt of bog $160 \mathrm{~m}$, ridges rise to $+235 \mathrm{~m}$. Peat layer of bog is transitional, depth of organogenous sediments, peat and sapropel, $5.9 \mathrm{~m}$ underlain by clay. Sample coll 1977 by O Kuznetsov.

\section{TA-1019. Mezhgornoye}

$7920 \pm 100$

Peat from 5.6 to $5.9 \mathrm{~m}$ depth. Pollen analysis attributes age of sample to middle Boreal.

\section{Zapovednoye series}

Zapovednoye bog is in Kemi dist between settlements of Shombe and Kepa in slightly hilly moraine plain, $+120 \mathrm{~m}$. Peat depth, $5.8 \mathrm{~m}$. Transitional peat deposit between fen and bog. Two samples coll 1977 by O Kuznetsov.

\section{TA-954. Zapovednoye}

$899 \pm 100$

Benthic peat layer from 5.5 to $5.8 \mathrm{~m}$ depth underlain by clay. Pollen analysis shows Boreal max of birch (beginning of B01).

\section{TA-955. Zapovednoye}

$6900 \pm 100$

Peat from 4.7 to $5 \mathrm{~m}$ depth. Pollen spectra indicate lower boundary of continuous curve of elm pollen (AT1).

\section{Shomba suo series}

Shomba bog is in Kemi dist near settlement of Shomba in undulating plain, +95 to $100 \mathrm{~m}$. Fen peat bed at $2.25 \mathrm{~m}$ depth. Two samples for dating coll 1978 by O Kuznetsov.

TA-1102. Shomba suo

Benthic peat from 2 to $2.25 \mathrm{~m}$ depth underlain by clay. Pollen analysis indicates optimum of Atlantic period (AT1).

TA-1103. Shomba suo

$3050 \pm 60$

Peat from base of lakelet in ridge-pool lake complex 1 to $1.25 \mathrm{~m}$ deep.

\section{Kepa series}

Kepa bog, Kalevala dist near Kepa settlement, in small depression in kame relief. Alt $+125 \mathrm{~m}$. Peat deposit transitional; depth of organogenous sediments $4.9 \mathrm{~m}$. Two samples coll 1977 by O Kuznetsov. 
TA-1017. Kepa

$8995 \pm 100$

Sapropel from benthic layer 4.7 to $4.9 \mathrm{~m}$ deep in contact with sand. Pollen spectrum displays max of birch (B01).

\section{TA-1018. Kepa}

$6115 \pm 100$

Peat from 3.75 to $4 \mathrm{~m}$ depth is in contact with sapropel. Pollen analysis displays optimum of Atlantic period (AT2).

\section{July suo series}

July bog, Kalevala dist W of Lake Kontokki, developed in narrow ravine in high-ridged denudate-tectonic relief. Borings of lacustrine bog sediments were carried out up to $6.5 \mathrm{~m}$ depth. Sediments are made up to $5.75 \mathrm{~m}$ of transitional fen peat and at $0.75 \mathrm{~m}$ of sapropel. Two samples coll 1974 by O Kuznetsov.

\section{TA-738. July suo}

Sapropel from 6.25 to $6.5 \mathrm{~m}$ depth, attributable to beginning of Atlantic period (ATI).

\section{TA-737. July suo}

Peat from 5.25 to $5.5 \mathrm{~m}$ depth in contact with sapropel. Pollen analysis shows optimum of Atlantic period (AT2).

\section{Kontokki series}

Landscape bog, Kalevala dist SW of Lake Kontokki, occupies narrow depression in denudate plain, $+202 \mathrm{~m}$. Fen peat bed, max depth of organic sediments, $7 \mathrm{~m}$. Six $\mathrm{m}$ of sediments are peat, $1 \mathrm{~m}$ is sapropel underlain by clay. Two samples coll 1974 by G Elina and O Kuznetsov.

\section{TA-730. Kontokki}

$8000 \pm 100$

Benthic sapropel, coll from 6.75 to $7 \mathrm{~m}$ depth, from pollen analysis, assigned to Boreal period (B02).

\section{TA-729. Kontokki}

$3200 \pm 60$ of spruce.

Peat from 4.25 to $4.5 \mathrm{~m}$ depth. Pollen analysis shows Sub-Boreal max

\section{No suo series}

No suo bog, Kalevala dist $\mathrm{E}$ of Lake Kontokki, occupies a narrow ravine between high eskers. Alt of esker ridges, $+170 \mathrm{~m}$, relative alt of ridges, ca $8 \mathrm{~m}$. Boring exposed bore well, $8 \mathrm{~m}$ deep. $4.25 \mathrm{~m}$ of bore hole is transitional peat; $3.75 \mathrm{~m}$ is sapropel. Sample coll 1972 by Elina and Kuznetsov.

\section{TA-581. No suo}

Sapropel coll near boundary of limnotelmatic contact at 4.75 to $5 \mathrm{~m}$ depth. Comment: pollen spectra display optimum of AT1 and beginning and distribution of spruce. 


\section{SE Prebelomorye}

This region unites territory of Prebelomorsk depression bordering on town of Belomorsk and $\mathrm{Vyg} \mathrm{R}$ in $\mathrm{W}$, on the boundary of Karelia with Arkhangelsk Region in E. Six samples from peat deposits of 2 bogs are listed.

\section{Zarutskoye series}

Zarutskoye bog, Belomorsk dist, SE of Nyukhcha village, on 3rd sea route of Prebelomorsk depression, $+20 \mathrm{~m}$. Raised bog peat bed, maximum depth $8 \mathrm{~m}$, underlain by sea clay and loamy soil. Five samples coll 1975 by G Elina and V Antipin.

TA-836. Zarutskoye

$8360 \pm 100$

Peat, depth 7.5 to $7.85 \mathrm{~m}$, from contact zone of fen and transitional layers. Comment: pollen analysis shows Boreal age (B02).

TA-835. Zarutskoye

$7120 \pm 100$

Peat from 6.25 to $6.5 \mathrm{~m}$ depth, ascribed by pollen analysis to $1 \mathrm{st}$ half of Atlantic period (AT1). Comment: dates appearance of spruce (empiric boundary).

TA-834. Zarutskoye

Peat from 5 to $5.25 \mathrm{~m}$ depth. Comment: pollen analysis indicates Upper Atlantic spruce pollen max.

TA-833. Zarutskoye

$3500 \pm 70$

Peat from 2.25 to $2.5 \mathrm{~m}$ depth. Comment: assigned to Sub-Boreal period by pollen analysis. Dates Sub-Boreal max of spruce.

TA-832. Zarutskoye

$1940 \pm 60$

Peat from 1 to $1.25 \mathrm{~m}$ depth. Comment: pollen analysis shows SubAtlantic max of spruce.

\section{Nyukhcha series}

TA-837. Nyukhcha

$\mathbf{5 0 1 0} \pm \mathbf{8 0}$

Peat from 4.15 to $4.3 \mathrm{~m}$ depth coll from Malyi Nyukhchensky Mokh bog. Belomorsk dist $\mathrm{E}$ of Nykhcha village, on 3rd sea terrace of Prebelomorsk depression, alt $20 \mathrm{~m}$. Raised bog peat bed, depth, $5 \mathrm{~m}$. Sample coll 1975 by V Antipin. Comment: pollen analysis indicates end of Atlantic period (AT2) and empiric boundary of spruce pollen.

\section{Central Karelia}

Territory between $64^{\circ} \mathrm{N}$ and $62^{\circ} \mathrm{N}$ has been least thoroughly studied. Present list contains descriptions of 7 samples coll from 3 peat bogs.

\section{Chelmuzhi series}

Bog along Nemina R, Medvezhyegorsk dist $\mathrm{E}$ of Chelmuzhi village, has been compressed into narrow valley of Nemina $R$ from which terrace sharply rises at alt, $+6 \mathrm{~m}$. Three samples coll 1971 by $\mathrm{G}$ Elina and $\mathrm{O}$ 
Kuznetsova from natural outcropping of peat bog with total thickness, $2.65 \mathrm{~m}$

TA-434. Chelmuzhi

$4480 \pm 60$

Peat from 1.3 to $1.35 \mathrm{~m}$. Comment: pollen analyses shows that these peat samples were deposited at beginning of Sub-Boreal period.

TA-433. Chelmuzhi

$4270 \pm 70$

Strongly mineralized peat from 1.15 to $1.2 \mathrm{~m}$ depth. Comment: pollen analyses indicate Sub-Boreal max of spruce.

TA-432. Chelmuzhi

$2975 \pm 60$

Peat from 0.7 to $0.75 \mathrm{~m}$ depth. Comment: pollen analyses show SubBoreal/Sub-Atlantic contact.

\section{Chudesnoye series}

Chudesnoye bog, Medvezhyegorsk dist NW of Lake Segozero, occupies narrow depression of lacustrine-glacial plain, at $+185 \mathrm{~m}$. Two samples of fen peat bed from 6m depth coll 1977 by V Antipin.

\section{TA-1023. Chudesnoye}

$\mathbf{8 4 5 0} \pm \mathbf{8 0}$

Peat from 5.5 to $5.75 \mathrm{~m}$ depth. Comment: pollen spectra show Boreal period for their deposition (beginning of $\mathrm{BO}_{2}$ ).

TA-1022. Chudesnoye $\mathbf{7 7 6 0} \pm 100$

Peat from 4.75 to $5 \mathrm{~m}$ depth. Comment: pollen analyses indicate end of Boreal period.

\section{Dry Lamba series}

Dry Lamba bog, Kontopohja dist Kivach Nature Reserve, among high hills of limno-glacial montane relief, at $+60 \mathrm{~m}$. Raised bog peat bed $8 \mathrm{~m}$ deep. Two samples coll 1976 by V Antipin.

TA-890. Dry Lamba

$8250 \pm 80$

Peat from 7.75 to $8 \mathrm{~m}$. Comment: pollen analyses from 7.75 to $8 \mathrm{~m}$ depth show middle of Boreal period.

TA-889. Dry Lamba

$7360 \pm 80$

Peat from 7.5 to $7.75 \mathrm{~m}$. Comment: pollen spectra show beginning of Atlantic period.

\section{South Karelia}

Territory $\mathrm{S}$ of $62^{\circ} \mathrm{N}$ has been studied rather thoroughly. The following describes 13 samples from 7 bog secs. Comment: materials of region under studly obtained by authors agree well with data pub 1967 by K Tolonen on Finland (Tolonen, 1967).

\section{Bezdonnoye series}

Bezdonnoye bog is in Suoyärvi dist W of Lake Samozero in moraine aqueoglacial undulating plain lying in basin between 2 low ridges, at 
$+123 \mathrm{~m}$. Fen peat bed is transitional. Max depth of organogenous sediments is $13.5 \mathrm{~m}$ of which $5.25 \mathrm{~m}$ are made up of peat and $8.25 \mathrm{~m}$ of sapropel. Four samples coll 1971 by V Antipin and O Kuznetsov.

TA-535A. Bezdonnoye

$9880 \pm 150$

Sapropel from 13 to $13.5 \mathrm{~m}$ from base of organogenous sediments. Comment: pollen spectra indicate absolute max of birch, which corresponds to beginning of Pre-Boreal period.

TA-534. Bezdonnoye

$9470 \pm 150$

Sapropel from $120 \mathrm{~m}$ depth. Comment: pollen analysis indicates contact of Pre-Boreal and Boreal periods.

TA-533. Bezdonnoye

$9085 \pm 120$

Sapropel coll from 12m depth.

TA-532. Bezdonnoye

$5065 \pm 70$

Peat from $5 \mathrm{~m}$ depth near limnotelmatic contact of sapropel and peat. Comment: pollen spectra of these sediments correspond to contact of Atlantic and Sub-Boreal periods.

\section{Mustu suo series}

Mustu suo bog lies in Pryazha dist $\mathrm{E}$ of Kindasovo village in extensive basin of Shuisk lowland of limno-glacial origin (Apykhtin et al, 1965). Alt marks contact of bog and waterless valley at $102.5 \mathrm{~m}$ depth. Bog peat bed transitional; max depth, 5.5m. Two samples coll 1973 by V Tchatchkhiani and $\mathrm{O}$ Kuznetsov.

TA-579. Mustu suo

$8670 \pm 100$

Benthic, in contact with clay, peat from 4.75 to $5 \mathrm{~m}$ depth. Pollen analyses indicate max of birch, which corresponds to Boreal period (end of B01).

TA-578. Mustu suo

Peat from 3.5 to $3.75 \mathrm{~m}$ depth. Appearance of spruce pollen is noticeable in pollen-analytical spectra.

\section{Kindasovo series}

Nenazvannoye bog is in Pryazha dist $\mathrm{N}$ of Kindasovo village in higher ridges of Shuisk lowland, at $+102.5 \mathrm{~m}$. Fen peat bed transitional, 4 to $4.5 \mathrm{~m}$ deep, underlain by clay. Three samples coll 1974 by V Antipin and O Kuznetsov, 2 samples from bore well in center of bog, 1 from periphery.

\section{TA-838. Kindasovo}

$8460 \pm 100$

Benthic peat from center of bog from 4.25 to $4.4 \mathrm{~m}$ depth. Pollen analyses assign sample to Boreal period (B01/B02).

\section{TA-855. Kindasovo}

$4150 \pm 40$

Peat from same site $(0.75$ to $1 \mathrm{~m}$ depth). Pollen-analytical spectra (sharp decrease of spruce pollen) attribute sediments to 2nd half of SubAtlantic period. 
TA-779. Kindasovo

Benthic peat from 2.32 to $2.6 \mathrm{~m}$ depth on periphery of bog. Pollen analysis indicates Sub-Boreal age of sediments.

\section{Rittu suo series}

Rittu suo lies in Pryazha dist NE of Kindasovo village in limnoglacial plain at $+100 \mathrm{~m}$. Raised bog peat bed from $3.15 \mathrm{~m}$ depth. Sample coll 1975 by V Tchatchkhiani and O Kuznetsov.

TA-580. Rittu suo

Benthic peat from 2.4 to $2.7 \mathrm{~m}$ depth, assigned by pollen analyses to end of Boreal period (B02).

\section{Koivu suo series}

Koivu suo in Pryazha dist borders on Rittu suo in W lying at $+97.5 \mathrm{~m}$. Fen peat bed 1.5 to $2 \mathrm{~m}$ deep. Two samples coll 1971 by V Tchatchkhiani and $\mathrm{O}$ Kuznetsov.

\section{TA-447. Koivu suo}

$5780 \pm 100$

Peat from 1.3 to $1.4 \mathrm{~m}$ depth underlain by clay. Pollen spectra show climatic optimum (AT2).

TA-448. Koivu suo

$2550 \pm 70$

Peat from 0.8 to $0.9 \mathrm{~m}$ depth. Pollen spectra clearly show contact of Sub-Boreal and Sub-Atlantic periods.

\section{TA-955. Hiili suo}

$8530 \pm 80$

Peat from 5.5 to $5.8 \mathrm{~m}$ depth from Hiili bog, Prionega dist SE of Petrozavodsk. Bog is on slope of individual elev massif at $+147 \mathrm{~m}$. Fen peat bed transitional, max peat depth, 6m. Sample coll 1976 by V Antipin and O Kuznetsov. Comment: pollen analyses and dates show Boreal period for formation of these layers, contact of $\mathrm{B} 01 / \mathrm{B} 02$, which do not confirm Donner's data (Donner, 1951) on formation of this bog in Late-Glacial period.

\section{REFERENCES}

Apukhtin, N L, Ekman, I M and Yakovleva, S V, 1965, New evidence relating to the existence of the Late-Glacial Belomor-Baltic sea-gate on the Onega-Ladoga isthmus Baltica, 2: Vilnius, p 99-112 (Russian).

Donner, I, 1951, Pollen-analytical studies of late-Glacial deposits in Finland: Finland Bull Comm geol, v 154, p 1-92.

Elina, G A, 1969, On the development of bogs in the SE part of the Prebelomor lowland: Bot Zh, 4, p 545-553 (Russian).

1971a, Correlation of the pollen-analytical spectra of the Holocene of the Karelian ASSR, Leningrad Region and Finland: Palynology of the Holocene, Moscow, p 91-104.

1971b, Bog types of the Prebelomor lowland in Bogs of Karelia and ways of utilizing them: Petrozavodsk, p 51-79 (Russian).

Pyavchenko, N I, Elina, G A, and Tchatchkhiani, V N, 1976, Basic stages in the history of vegetation and of peat accumulation in $W$ part of the Baltic Shield in the Holocene: Comm on study of Quaternary period Bull, v 45, p 3-24 (Russian).

Tolonen, K, 1967, Über die Entwicklung der Moore im finnischen Nordkarelien: Annales Bot Fennicae, v 4, no. 3, Helsinki, p 220-416.

Vasari, Y, 1962, A study of the vegetational history of the Kuusamo district (NE Finland) during the late-quaternary period: Annales Bot Soc Zool Bot Fennicae "Vanamo", v 33, no. 1, Helsinki, p 140. 